\title{
A tensão entre o conservadorismo e as aspirações à transformação social no protestantismo brasileiro. Em diálogo com a análise das raízes calvinistas no protestantismo alemão e norte-americano por Paul Tillich*
}

\author{
Etienne Alfred Higuet ${ }^{* *}$
}

\begin{abstract}
RESUMO
$\mathrm{O}$ artigo pretende mostrar, a partir de análises de Tillich, que as raízes calvinistas do protestantismo norte-americano se transmitiram ao protestantismo brasileiro e induzem até hoje uma tensão permanente entre o conservadorismo e as aspirações à transformação social. Pois, encontramos no protestantismo brasileiro os mesmos contrastes que no calvinismo em geral e anglo-saxão em particular. O resultado pode ser tanto um abstencionismo político quanto uma participação em vista de conquistar um espaço social e econômico para as comunidades evangélicas, ou ainda uma crítica radical do sistema econômico e social e um engajamento em vista de uma transformação profunda e até revolucionária. O texto procura mostrar isso através de um breve panorama histórico e atual do protestantismo brasileiro e de alguns exemplos significativos.

Palavras-chave: protestantismo, calvinismo, missão, transformação social, conservadorismo, política.
\end{abstract}

* Versão adaptada em português de HIGUET, 2019, p. 369-395.

** Professor aposentado do Programa de Pós-Graduação em Ciências da Religião da Universidade Metodista de São Paulo. Presidente da Associação Paul Tillich do Brasil. E.mail: etienne.higuet@gmail.com.Lattes: http://lattes.cnpq.br/5600938581821983. 


\title{
The tension between conservatism and aspirations for social transfor- mation in Brazilian Protestantism. In dialogue with the analysis of Calvinist roots in German and American Protestantism by Paul Tillich.
}

\begin{abstract}
The article intends to show, from Tillich's analysis, that the Calvinist roots of American Protestantism were transmitted to Brazilian Protestantism and induce to this day a permanent tension between conservatism and aspirations to social transformation. For, we find in Brazilian Protestantism the same contrasts as in Calvinism in general and Anglo-Saxon in particular. The result may be both political abstentionism and participation to conquer a social and economic space for evangelical communities, or even a radical criticism of the economic and social system and an engagement in view of a profound and even revolutionary transformation. The text seeks to show this through a brief and current historical overview of Brazilian Protestantism and some significant examples.

Keywords: Protestantism, Calvinism, mission, social transformation, conservatism, politics.
\end{abstract}

\section{Introdução}

Numa primeira parte, procuro examinar, a partir dos escritos tillichianos sobre o socialismo, a possível passagem do protestantismo ao socialismo. Para Tillich, era mais fácil passar do calvinismo ao socialismo, enquanto era quase impossível a partir do luteranismo. Para ele, havia, ao sair da Grande Guerra, um abismo entre as igrejas luteranas e o proletariado, entre a mensagem transcendente do cristianismo tradicional e as esperas imanentes dos movimentos revolucionários (TILLICH, 1957, p. xiii). Os socialistas religiosos tentaram realizar esta transição assim mesmo. Nessa perspectiva, Tillich desenvolveu os conceitos de utopia, kairos, demônico, princípio protestante ou profético e estruturação (Gestaltung) protestante (IBID., p. v-xxv).

Já na época de Lutero, a ala esquerda da Reforma: anabatistas, antitrinitarianos, Schwärmer ou entusiastas pretendiam transformar a sociedade, de modo pacífico ou violento. ${ }^{1}$ Tillich reencontra sua he-

\footnotetext{
1 A historiografia discute a terminologia, pois ela foi, muitas vezes, imposta pelos adversários desses grupos. A "ala esquerda" da Reforma e a "Reforma radical” são termos que incluem tradicionalmente grupos e indivíduos anabatistas, entusiastas e antitrinitarianos. Para uma discussão atual dos fenômenos subjacentes a essas noções, ver: HEAL; KREMERS, 2017.
} 
rança entre "os protestantes americanos, cuja forma de cristianismo não procede diretamente da Reforma, mas constitui um efeito indireto desta através do radicalismo evangélico (TILLICH, 1970, p. 268)”. O protestantismo brasileiro deriva, na sua imensa maioria, das missões organizadas pelo radicalismo evangélico norte-americano (metodismo, presbiterianismo, batismo, adventismo, pentecostalismo) e recebeu do mesmo a tensão entre o abstencionismo político e a preocupação pela transformação social. Tratarei disso na segunda parte. Tratar-se-á, sobretudo, de mostrar como a descrição do calvinismo por Tillich ajuda a compreender o protestantismo brasileiro, introduzido pelos missionários norte-americanos, os quais trouxeram uma forma de calvinismo produzida nos países anglo-saxões. No Brasil de hoje, grande parte do protestantismo aparece como expressão das forças mais conservadoras, mas certas correntes protestantes foram, desde os anos sessenta do século passado, precursoras da Teologia da Libertação. É o caso do movimento "Igreja e Sociedade na América latina (ISAL)" e da "Confederação evangélica do Brasil", que organizou a "Conferência do Nordeste". Entre os teólogos dessa linha, brasileiros ou estrangeiros vivendo ou tendo vivido no Brasil, é preciso mencionar Rubem Alves, Waldo César, Júlio de Santa Ana, Walter Altmann e, sobretudo, Richard Shaull, do qual descreverei mais particularmente o pensamento e a ação.

\section{Protestantismo e transformação social segundo Paul Tillich}

Para Tillich, a história do protestantismo está intimamente ligada à história do espírito burguês e da sociedade que o encarna. Embora, na origem, o protestantismo tenha rejeitado com todas as forças o espírito burguês ou espírito da finitude autossuficiente, tanto na sua forma eclesial hierárquica quanto na sua forma humanista tradicional, perdeu grande parte do seu potencial de protesto ao tornar-se igreja. O vazio deixado pelo fim da autoridade sacerdotal foi preenchido pelo Estado no luteranismo (a igreja torna-se um departamento da administração pública) e pela sociedade no calvinismo (TILLICH, 1990, p. 235).

\subsection{O protestantismo alemão}

Na introdução à Era protestante, Tillich afirma: "O meu ingresso no movimento socialista religioso significava, para mim, uma ruptura 
definitiva com o idealismo filosófico e o transcendentalismo teológico. Ele me abria os olhos para o sentido religioso do calvinismo político e do sectarismo social, em oposição ao caráter sacramental predominante na minha própria tradição luterana (TILLICH, 1957, p. xiv)." Seria possível ir do luteranismo, profundamente oposto a toda utopia social, inclusive a metafísica do progresso, ao socialismo, que carrega a exigência de uma ordem social mais justa? Tillich reconhecia que era quase impossível, para um povo formado no luteranismo, de chegar ao socialismo a partir da religião.

No artigo Protestantismo e romantismo político, de 1932, contemporâneo de $A$ decisão socialista, Tillich mostra a afinidade do luteranismo com o romantismo político conservador e revolucionário, em oposição à concepção calvinista do Reino de Deus. Para Tillich, a divisão entre o tipo luterano e o tipo reformado do protestantismo "abre hoje (1932) um abismo político intransponível: aqui a sacralização sacramental do que existe, lá a exigência profética de submeter o que existe à lei divina (TILLICH, 1994a, p. 11)”.

No protestantismo luterano, a esfera toda da lei natural divina está ausente. No lugar dela, temos a ideia de uma providência divina irracional, que age diretamente através dos poderes históricos. O combate iniciado por Lutero contra a lei racional se volta especialmente contra o Estado democrático. Do mesmo modo que Deus é radicalmente personalizado, o Estado deve se encarnar numa pessoa, por exemplo a do Führer. A forma de vida democrática é percebida como mecanização insuportável das forças irracionais, como um sistema destruidor da pessoa humana. Na linha dessa ideologia luterana, os poderes míticos originários (o solo, a raça, o povo, o chefe) chegam a pretender representar a vontade divina (TILLICH, ibid., p. 12-14).

Já que um ser finito não pode apreender o infinito, o calvinismo, ao contrário, "se opõe a todo tipo de poder sagrado, desde os poderes do solo até a instituição sacerdotal sacramental. Ele concebe o Reino de Deus como uma tarefa que deve ser cumprida com a colaboração da luta da comunidade. Ela não se realiza apenas no além, mas também aqui na terra (IBID., p. 11)". A eleição de cada indivíduo se manifesta na sua luta em vista de realizar a vontade divina. "Essa vontade se expressa na lei, que é, ao mesmo tempo, divina e natural, cristã e humanista 
(IBID.)." Ela não diz respeito apenas à vida interior do indivíduo, mas também à vida da sociedade. Em consequência, a realização progressiva do Reino de Deus será um resultado da cristianização da sociedade, provocada pela proclamação e o ensino da igreja (TILLICH, 1994b, p. 201-202).

Logo, Deus deve reinar não apenas no céu, mas também na terra, especialmente no Estado e na política. A igreja deve criticar os poderes terrestres do ponto de vista da vontade divina encontrada na Bíblia. É que a concepção bíblica do Reino de Deus providencia a medida dos reinos terrestres. A teologia calvinista está assim na origem da nossa democracia revolucionária ocidental (TILLICH, 1994c, p. 174-175). Já que todos os vínculos sagrados originários foram rompidos, as funções eclesiásticas e políticas não são mais determinadas pelo ser sagrado, mas pela natureza das coisas e as suas leis, entendidas de modo racional objetivo. $\mathrm{O}$ movimento histórico anda na direção de uma supressão progressiva dos demonismos sagrados e da instauração de um mundo submetido à vontade de Deus e às normas de uma humanidade ativa. A própria igreja é apenas um grupo de ação, não uma realidade sacramental (TILLICH, 1994a, p. 11-12).

Por esse motivo, "as comunidades devem criar e manter sua própria constituição. O caráter facultativo da adesão e a organização democrática aproximam esta espécie de protestantismo do tipo sectário, e tornam possível a fusão dos dois tipos. Temos aqui a preparação do individualismo da sociedade burguesa, da erosão do Estado e da significação fundamental do indivíduo (TILLICH, 1990, p. 238). Tanto a comunidade quanto o indivíduo estão impregnados pelo espírito da sociedade burguesa. Daí nasce a conviç̧ão de que a humanidade burguesa é a realização da ideia cristã. Portanto, a dominação do princípio comunitário no calvinismo não implica em nenhuma oposição de princípio ao sistema capitalista. ${ }^{2}$ "Um otimismo ativo, imenso e poderosamente eficaz, identifica instintivamente o Reino de Deus com a humanidade

2 No mundo anglo-americano, o princípio calvinista da comunidade suscitará a exigência de colocar uma porção importante dos próprios ganhos ao serviço da comunidade e dos pobres (TILLICH, 1990, p. 239). 
burguesa inteiramente humanizada, pacificada e concebida de modo cristão (TILLICH, 1990, p. 239)". ${ }^{3}$

Daí nasce a ideologia política do calvinismo. A identificação do modo de vida burguês com o reino de Deus constitui uma adesão ao domínio da classe burguesa no regime capitalista. O sucesso social e profissional torna-se abusivamente um sinal religioso de predestinação e eleição, o que provoca o desprezo pela situação de classe oprimida de milhões de pessoas que não tiveram a mesma sorte. A ideologia não se contenta em glorificar a classe burguesa, mas justifica também a dominação do mundo pelos povos anglo-saxões e seu imperialismo econômico, atribuindo a eles o papel de representantes da humanidade cristã. Isso foi criticado pela teologia de Barth: "O abismo aberto por Barth entre o mundo e Deus [...] desfere um golpe decisivo à identificação ideológica ingênua entre o Reino de Deus e a sociedade burguesa (TILLICH, 1994a, p. 14)". ${ }^{4}$

\subsection{O protestantismo na América do Norte}

$\mathrm{O}$ que foi dito sobre o calvinismo na Alemanha se aplica em especial ao calvinismo norte-americano. Tillich observa que os protestantes americanos são, em grande maioria, de tradição calvinista e, por conseguinte, tendem a julgar os reinos deste mundo segundo os critérios do Reino de Deus. Ao opor-se aos poderes sagrados da origem e visar a realização do Reino de Deus pela transformação desse mundo conforme a justiça e a vontade de Deus, o calvinismo norte-americano se

3 Tillich repara também a adesão conservadora às convenções da sociedade burguesa em matéria de sexualidade e matrimônio, já que o caráter sacramental do último foi destruído.

4 Tillich reconhece os efeitos positivos do juízo formulado por Karl Barth, mesmo se, em outro lugar, ele critica os motivos do teólogo da Basiléia: "A ortodoxia protestante, na pessoa do famoso teólogo Karl Barth, ele mesmo um ex-socialista religioso, recusou todo vínculo entre a interpretação religiosa da ideia de Reino de Deus e a sua interpretação humanista. Barth insistia e ainda insiste na pura transcendência da esperança religiosa e na pura imanência dos programas políticos. Ele não admite nem o pano de fundo cristão do secularismo moderno, nem a interpretação cristã do movimento proletário. Ele corta todos os vínculos entre o Reino de Deus e a história humana; ele pôde divulgar essa doutrina com tanta facilidade porque ela concorda tanto com a tradição luterana alemã quanto com as tendências do pensamento burguês. Desse modo, ele contribuiu para a anulação da ação do socialismo religioso (TILLICH, 1994c (1934), p. 180-181). Ainda poderemos constatar a afinidade da "teologia pentecostal da prosperidade" com a ideologia política e social calvinista. 
inscreve na linhagem dos profetas. Mas ao passar do protesto profético em nome da lei natural e divina para a autonomia racional característica da modernidade e à identificação da sociedade burguesa com o Reino de Deus, ele se torna ideológico no sentido pejorativo de "máscara da realidade" (RICHARD, 1990, p. xx-xxiii).

Segundo um artigo publicado nos Estados Unidos em 1936, dedicado às funções sociais exercidas pelas igrejas, as igrejas protestantes americanas, herdeiras do calvinismo, se definem mais empiricamente e sociologicamente do que de modo religioso ou místico (TILLICH, (1936) 1965, p. 106-119). Para elas, a ideia mística da "Igreja invisível" única não faz sentido. Uma igreja, isto é, uma comunidade particular, é o resultado da associação livre de um grupo de cristãos. O recrutamento é feito na base do grau de perfeição moral e religiosa. O sagrado não está dado, mas depende da decisão e realização do ser humano. As igrejas se caracterizam, antes de tudo, pela ideia federativa e associativa, e são, assim, grupos sociais que possuem certos interesses e objetivos em comum, mas competem também entre si. Elas podem cooperar em torno de certos projetos sociais, mas isso não as impede de fazer propaganda a respeito da superioridade concreta das suas instalações ou de seus dirigentes. Em consequência, a casa comunitária serve, ao mesmo tempo, para o culto, as discussões políticas e os encontros sociais.

É uma consequência do tipo religioso teocrático, ao qual elas pertencem. A teocracia, que procura realizar a vontade de Deus, usa o poder político para colocar as instituições sociais e a personalidade moral em acordo com os mandamentos do Reino de Deus. No seio do cristianismo, é o puritanismo - a forma calvinista anglo-saxã - que é a tentativa mais significativa de instituir a teocracia. Daí o significado extraordinário conferido ao Antigo Testamento pelo calvinismo puritano. Isso se expressa através de prescrições a respeito da santificação do domingo, pela proibição de bebidas alcóolicas, por leis contra o jogo e a ociosidade, e pela regulação precisa da vida familiar e sexual. A Bíblia se torna o princípio diretor da vida social e política, pois fornece instruções completas e obrigatórias para todas as atividades humanas. Isso se reflete até na pregação, que interpreta a Escritura de modo autoritário. 
Na teocracia, domina o "princípio da autoridade democrática", em oposição a toda concepção igualitária da democracia. Esse princípio se encarna no presbitério, grupo de clérigos e de anciãos escolhidos por cooptação, que administra a comunidade eclesial e, desse modo, domina também em ampla medida a vida social e até o Estado. Desprovido de autoridade sacramental, o presbitério pode ser objeto de crítica. Embora a democracia não possa ser deduzida do calvinismo autêntico, o princípio de autoridade democrática pode ter sido uma etapa na passagem para a democracia.

A democracia americana surgiu então como movimento contrário ao princípio presbiteriano. Sua força espiritual se baseia mais sobre o individualismo religioso que, por sua vez, deriva de duas fontes: a doutrina do direito natural e o "espiritualismo" religioso. Em última instância, essas fontes procedem de uma origem comum: o princípio de identidade entre o espírito divino e o espírito humano, como na mística. Em oposição ao calvinismo originário e ao presbiterianismo, o protestantismo sectário assumiu a mística na qual o indivíduo deve se realizar, exercendo a partir dela a sua influência sobre a vida social. Em virtude do direito natural, no qual se expressa a vontade do criador divino, na comunidade cristã assim como no Estado, é o povo que detém o poder, enquanto associação de indivíduos nascidos livres.

Os grupos sectários defendiam a ideia de tolerância contra a ditadura religiosa do puritanismo. A autonomia e a liberdade na opção pelo batismo de adultas e a escolha da pertença religiosa expressam essa ideia. O individualismo encontrou a sua expressão mais radical entre os Quakers, com a sua doutrina da "luz interior", que dirige aquele que está aberto ao espírito divino. O individualismo religioso recebeu também um poderoso reforço pela expansão do metodismo, sobretudo nos territórios recém conquistados do Oeste norte-americano. Sua tendência à conversão individual, sua crítica da doutrina da predestinação, sua doutrina da liberdade da vontade e sua fé na capacidade geral do ser humano em se deixar guiar pela razão forneceram à sensibilidade democrática novos e decisivos impulsos.

$\mathrm{Na}$ Europa, tanto os protestantes como os católicos enxergavam no espiritualismo e no individualismo religioso um grande perigo. Por esse motivo, as comunidades batistas e os outros grupos do movimento 
espiritualista foram perseguidos com tanta violência, que apenas se salvou um pequeno resto na Inglaterra e que foi só na América que eles puderam fundar grandes comunidades. Contrariamente à Europa, a declaração dos direitos humanos e a democracia encontraram na América um fundamento religioso.

Por outro lado, para Tillich, não é o puritanismo, mas o liberalismo radical, como o encontramos na proclamação dos direitos do homem, que reforçou a atitude capitalista. $\mathrm{O}$ capitalismo ingressou nas igrejas no século XIX, pela introdução dos métodos financeiros modernos na sua administração. A influência dos leigos se tornou cada vez mais forte e os departamentos administrativos das comunidades se tornaram, cada vez mais, potências econômicas. Construções onerosas fizeram crescer a dependência das comunidades em relação com seus membros ricos. Acreditava-se que esse desenvolvimento constituía uma "promoção do bem-estar". Isso se viu primeiro nas igrejas originariamente liberais, entre os batistas e os metodistas. Pode-se dizer que o capitalismo e a técnica foram sustentados pela religião, pois via-se neles meios pelos quais a América poderia cumprir sua missão no Estado e na Igreja.

O movimento do Evangelho social (Social Gospel) foi uma das expressões do calvinismo político nos Estados Unidos, e foi trazido ao Brasil pelos missionários protestantes. Para Tillich, trata-se de uma refundição da teologia toda na perspectiva da moral social. Inspira-se nas ideias expostas por Kant em $A$ religião nos limites da simples razão e retomadas por Ritschl e sua escola. Ingressou nos Estados Unidos graças a Walter Rauschenbausch (1861-1918). A teologia de Ritschl já visava o desenvolvimento da personalidade burguesa, como personalidade individual forte, ativa e disciplinada do ponto de vista moral. Ela defendia certo liberalismo social e político e um pensamento autônomo no campo científico, além da recusa de toda autoridade (TILLICH, 1972, 14-15; 84; 276). Por sua vez, o movimento do Social Gospel foi criado por um grupo de protestantes liberais progressistas, em resposta aos problemas sociais provocados pela industrialização e a urbanização rápidas e pela imigração crescente. Dava a prioridade à salvação social em relação com a salvação individual e ressaltava a imanência de Deus e a doutrina da encarnação. Valorizava mais as boas obras do que as crenças. 
O Evangelho social apoiava o movimento operário e reclamava um Estado intervencionista de bem-estar social, pois condenava como não cristãs as práticas capitalistas de formação dos preços e dos salários. Visava uma sociedade cristianizada, na qual a cooperação, o respeito mútuo e a compreensão substituiriam a competição e o conflito entre as classes sociais e econômicas. Contudo, em razão do fracasso dos seus esforços para alcançar as classes laboriosas, os partidários do movimento se limitaram ao meio protestante liberal de classe média, contribuindo para tornar esse meio mais progressista.

Líder intelectual do movimento no começo do século XX, Walter Rauschenbausch, ministro de uma igreja batista de imigração alemã, conseguiu unir o evangelicalismo pietista alemão, o liberalismo teológico e o cristianismo social, ao encarnar o Reino de Deus na realidade social. O Reino de Deus pertence a um futuro desconhecido, mas é latente no presente e ativo nos momentos de crise e de mudança. O papel da igreja e dos cristãos é anunciar o reino, encontrá-lo no presente e incorporá-lo ao futuro como realização e finalidade de cada um de nós (OSHATZ, 2003). O Evangelho social foi acusado pelo fundamentalismo de priorizar a salvação social em relação com a regeneração das almas individuais em Cristo. A fé cristã se reduziria a uma inspiração para a ação social. A teologia liberal estaria exagerando a imanência de Deus na sociedade humana e tornaria Deus uma componente sem relevância do projeto essencialmente humano de reforma social. Do seu lado, Reinhold Niebuhr (colega e amigo de Tillich) criticou o idealismo ingênuo do Social Gospel e preconizou uma "revolta gradual contra toda a cultura liberal da época", refúgio confortável da burguesia triunfante. Aproximava-se assim do Tillich do socialismo religioso, usando como ele as ferramentas marxistas de análise da sociedade em termos de classes, de relações de força e de poder (RICHET, 2006, n. 2).

\section{Conservadorismo e transformação social no protestantismo brasileiro}

\subsection{Breve caracterização do protestantismo no Brasil}

O protestantismo brasileiro provém, na sua imensa maioria, das missões organizadas pelo radicalismo evangélico norte-americano (me- 
todismo, presbiterianismo, batismo, adventismo, pentecostalismo) e recebeu dele a tensão entre o abstencionismo político e a preocupação pela transformação social. O protestantismo brasileiro - pelo menos as igrejas de origem missionária - é, ainda hoje, uma projeção do protestantismo norte-americano, alimentado pelas ideias da religião civil e acompanhando as ondas sucessivas de conservadorismo das igrejas dos Estados Unidos, seus debates e suas contradições. O puritanismo continua sendo a sua base de sustentação, com seus princípios de liberdade religiosa em relação com o Estado, liberdade litúrgica e ascetismo moral. Mas, por causa da sua situação minoritária, as igrejas protestantes brasileiras assimilaram as ideias messiânicas da religião civil norte-americana "para uso interno", contrariamente ao que acontecia nos Estados Unidos.

Os missionários da segunda metade do século XIX e do início do século XX, sob a influência do movimento evangelista nascido na Europa, mas difundido sobretudo nos Estados Unidos, mostravam a preocupação de oferecer uma espécie de frente única, baseada sobre alguns princípios doutrinais comuns. Assim a identidade "evangélica", essencialmente individual, significando o compromisso da pessoa com os princípios doutrinais fundamentais, acabou caracterizando a maioria das denominações protestantes. Oriundo dos Estados Unidos, em parte através de organizações missionárias interconfessionais, o protestantismo missionário brasileiro tinha intenções fortemente pragmáticas: pretendia ser um elemento de mudança da sociedade pela transformação dos indivíduos. A ideia da conferência missionário de Edimburgo (1910), de "cristianizar" como símbolo para "colonizar", foi adotada pelas missões no sentido da teologia calvinista do "Reino de Deus" e do "povo eleito". O conceito de "Reino de Deus" recebia o seu sentido a partir do "sonho americano", assim como o conceito de "povo eleito", encarregado de ampliar o reino de Deus.

A teologia dominante nas missões norte-americanas era a de John Wesley, fundador do metodismo, desenvolvida pelos movimentos de reavivamento. O mecanismo da salvação passava pela consciência da

5 Os protestantes brasileiros preferem em geral ser chamados de "evangélicos". O termo "protestante" é usado sobretudo pelos sociólogos, ao passo que "crente" se tornou pejorativo, por ser usado pelos católicos. 
culpa, seguida pelo ato voluntário da aceitação da oferta de salvação, pela justificação e pela santificação progressiva. Para a teologia "conversionista" missionária, a fé dependia da experiência emocional pessoal, a conversão era individual e consistia na ruptura abrupta do indivíduo com seu meio cultural, através da adoção de novos modos de conduta, opostos àqueles nos quais tinha sido educado. Essas características continuam presentes até hoje. Isso pode causar conflitos com a pertença denominacional, facilmente trocada. Outro aspecto importante é o uso da Bíblia, cuja leitura leva ao desenvolvimento pessoal e social. As organizações para-eclesiásticas veem na Bíblia um instrumento de renovação ética. Salvo exceções - como no caso dos batistas - as igrejas do protestantismo chamado histórico apresentam um crescimento apenas vegetativo e constituem uma pequena minoria dos cristãos evangélicos no Brasil.

Os pentecostais, oriundos das igrejas missionárias, nos Estados Unidos ou já no Brasil, representam atualmente a imensa maioria dos evangélicos. ${ }^{6}$ Os movimentos chamados de neopentecostais, a partir dos anos oitenta do século passado, estão centrados na pessoa do líder, nos milagres de cura divina e na teologia da prosperidade, e insistem menos na necessidade de restrições de ordem moral e cultural para alcançar a benção divina. Podemos citar a igreja "Deus é amor", a Igreja Universal do Reino de Deus, A Igreja Internacional da Graça de Deus, a Igreja Mundial do Poder de Deus e a Igreja Renascer em Cristo (MENDONÇA, 1989, p. 37-86).

Independentemente das particularidades dos diversos grupos, os estudos de ciência das religiões reconhecem algumas características comuns aos evangélicos brasileiros:

(1)Uma predominante leitura fundamentalista (literalista, a partir das ideias dos fundamentos da fé) do texto sagrado cristão, a Bíblia; (2) ênfase na piedade pessoal na busca da salvação da alma (influência do puritanismo e do pietismo dos pioneiros missionários que vieram do sul dos EUA, no século 19, ao Brasil); (3) frequentes posturas de rejeição das manifestações culturais não cristãs do país (fruto da mesma ação de missionários); (4) um isolamento das demandas sociais (resultante da espiritualização das questões da existência individual e social), entre elas a participação política (CUNHA, 2017, p. 14).

6 No seu conjunto, os evangélicos alcançam mais de $22 \%$ da população, segundo o censo de 2010. É provável que, desde então, a proporção tenha aumentado mais ainda. 
Desde os anos oitenta, no contexto da nova ordem mundial resultando dos progressos do capitalismo globalizado, o mundo evangélico brasileiro se caracteriza pela hegemonia pentecostal absoluta, a procura de inculturação no meio urbano e o surgimento da cultura gospel, marcada pelo desenvolvimento de uma religiosidade midiática (aquisição de espaços importantes na mídia, especialmente rádio e $\mathrm{TV}$, e a ocupação de espaços no universo cibernético, assim como a construção de um modo de ser evangélico a partir da interação com a mídia), pela identificação dos evangélicos como um setor do mercado e pela ampliação do mercado da música e dos seus derivados no setor de lazer. A reação do catolicismo e do protestantismo histórico ao avanço do pentecostalismo se concretiza no sucesso de grupos de "reavivamento" ou de "renovação carismática" no seio dessas igrejas. No contexto de exclusão social do capitalismo globalizado, as tendências religiosas da "teologia da prosperidade" e da "guerra espiritual" pregam a inclusão social através de promessas de prosperidade material condicionada pela fidelidade material e espiritual a Deus. É preciso também “destruir o mal" que impede que a sociedade alcance as bençãos da prosperidade. Em consequência, os "filhos do rei" devem invocar o poder todo ao qual têm direito, para conduzir uma guerra contra as "potências do mal" (CUNHA, 2017, p. 19-27).

\subsection{Os evangélicos e a política (Cf. CUNHA, 2017, p. 45-159)}

Os evangélicos estão presentes na política partidária desde o século XIX, mas até os anos oitenta do século XX, sua presença no parlamento era bastante simbólica. Isso correspondia à atitude de absenteísmo político devida à compreensão da separação radical entre a igreja (lugar do bem) e o mundo (lugar do mal), à moral individualista e à ausência de preocupação pelas coisas deste mundo. Os objetivos da igreja eram, sobretudo, a pregação espiritualizada da mensagem cristã, em vista da conversão, a adesão de novos fiéis e a salvação da alma. Isso se refletia nas atividades das igrejas, dedicadas, na maior parte, à vida interna das congregações, segunda a máxima: "O crente não mexe com política". A participação política dos crentes devia se restringir à obrigação do voto e ao respeito e à obediência às autoridades estabelecidas por Deus (segundo Paulo e a doutrina luterana dos dois reinos). A situação co- 
meça a mudar a partir da constituinte de 1933, quando a Confederação Evangélica do Brasil convidou os evangélicos a lançar candidatos, a fim de barrar a influência católica e de defender a laicidade do Estado e o ensino público gratuito, o divórcio, o pacifismo e a liberdade de pensamento e de crença, entre outras coisas. A partir daí, a participação política dos evangélicos de todo tipo não parou de crescer. Em 1986, foi formado o primeiro "bloco político evangélico" no Congresso Nacional. Doravante, o novo leme é: "Irmão vota em irmão". Atualmente (2017) há uma frente parlamentar evangélica importante e outras frentes religiosas, com a participação de evangélicos, como a frente parlamentar pela defesa da vida e da família. ${ }^{7}$

Nos últimos anos, tratou-se de ir de encontro aos movimentos sociais que defendem a extensão dos direitos das "minorias": mulheres, homossexuais, indígenas, negros (e, com eles, suas religiões). A defesa da moral cristã, da família e dos bons costumes tornou-se prioritária. Além disso, não podemos esquecer o anticomunismo profundo e quase obsessivo, que já tinha levado as igrejas evangélicas a apoiar o golpe civil-militar de 1964. Graças à sua participação política, as igrejas evangélicas não pararam de aumentar sua influência nos meios de comunicação, sobretudo a Igreja Universal do Reino de Deus, dona da rede Record de televisão, e a Assembleia de Deus.

Entretanto, alguns grupos evangélicos reagiram contra a atitude complacente e corrupta do bloco parlamentar evangélico, como o Movimento evangélico progressista (MEP) e a Associação Evangélica brasileira. A plataforma política dos grupos conservadores contém prioritariamente a luta contra a legalização do aborto, contra a descriminalização das drogas e a discussão das questões de gênero ("ideologia de gênero") e de política ("Escola sem partido") nas escolas públicas. Eles criaram um amálgama entre a ideologia de gênero, o marxismo e o Partido dos Trabalhadores. Eles são vistos pelos progressistas como ameaça ao Estado laico, aos direitos das mulheres, dos negros e dos LGBTQI+.

7 O artigo foi elaborado em 1917 e não inclui os anos subsequentes, com a campanha eleitoral, a eleição de Jair Messias Bolsonaro como presidente e os dois primeiros anos do seu mandato. Podemos constatar que a mesma polarização se mantém até hoje, em particular entre os apoiadores e os adversários evangélicos do Governo Bolsonaro. 
Do lado progressista, precisamos mencionar a participação na corrente teológica do Evangelho social, no movimento ecumênico e nos projetos defendidos pela Confederação Evangélica do Brasil (CEB). Foi a CEB que organizou a histórica conferência do Nordeste, sobre o tema: "Cristo e o processo revolucionário brasileiro" (1962), o que provocou sua perseguição e final dissolução. Atualmente, numerosos evangélicos participam de muitos programas e organismos sociais de alívio da pobreza, assistência à saúde e à habitação popular, de alfabetização e educação popular, ajuda aos migrantes, luta contra as desigualdades regionais, luta contra o racismo, o machismo e todas as formas de intolerância, ou a favor da justiça econômica e de gênero, e da ética na política. Podemos mencionar a "teologia da missão integral", "Visão mundial", a rede nacional de ação social e a rede Fale, Diaconia, a coordenação ecumênica de serviços (CESEP), Koinonia presença ecumênica e serviço e a rede ecumênica da juventude.

As igrejas tendem a não querer tomar posição sobre questões como a sexualidade, a ética, a política, a justiça sociopolítica, econômica e de gênero, e a cidadania. Ao contrário, elas espiritualizam essas questões e individualizam a resposta: cada cristão deve saber tomar as próprias decisões sob a orientação de Deus. Por outro lado, as igrejas instrumentalizam muitas vezes sua ação social para fazer proselitismo ou para construir uma imagem positiva junto ao grande público. Nesse contexto, líderes evangélicos se associam ao poder, em vista de manter ou ganhar posições na vida política ou de conseguir algum benefício para sua igreja: financiamento de construções, visibilidade social, aquisição de espaços de rádio e TV. Eles aproveitam a visibilidade crescente conseguida na mídia religiosa e secular e nas redes sociais, para divulgar sua teologia baseada na visão de um Deus guerreiro e belicoso, sustento de ideologias racistas, sexistas e homofóbicas.

\subsection{Alguns exemplos significativos de compromisso evangélico em vista da transformação social}

\subsubsection{Polêmica a respeito do Evangelho Social}

O movimento do Evangelho Social continua existindo no Brasil, como um dos componentes do evangelismo progressista. Ainda é 
objeto da crítica acerba de setores conservadores e fundamentalistas presentes nas redes sociais. Um blog evangélico conservador denuncia o movimento como "a vergonha do Evangelho Social". Para o blog, eles "têm vergonha do Evangelho do Cristo". Apesar das realizações sociais positivas, eles comprometem a fé bíblica e desonram a Deus, pois este não confiou à igreja a missão de resolver os problemas do mundo. O Evangelho Social é uma doença mortal para o "povo da fé": ele reforça a ideia de que a salvação poder ser conseguida pela prática das boas obras, deixando de lado as diferenças em favor do bem comum, tratando os outros como se amaria ser tratado, agindo de modo moral, ético e sacrificial e que, ao agir assim, as pessoas se tornarão agradáveis a Deus. Não! Esses esforços são enganação, pois desprezam a salvação de Deus e rejeitam a sua justiça perfeita. Assim, o Evangelho Social prega um "outro Evangelho" e contribui a preparar um reino completamente contrário às Escrituras, pois a nossa cidade está no céu, de onde aguardamos o salvador, o Senhor Jesus Cristo. Este voltará do céu para arrebatar aqueles que acreditam nele, enquanto o reino terrestre será o do Anticristo. Não vale a pena associar-se a fiéis de outras crenças em vista da procura da paz, da preservação do meio ambiente ou da justiça para todos. O que importa realmente ao coração de Deus é que todos se arrependam e acreditem no Evangelho. Afinal de contas, o Evangelho Social é um movimento esquerdista nascido nos Estados Unidos, que influenciou a Teologia da Libertação e a Teologia da Missão Integral, e que apoia a "vergonhosa teologia gay" (ou queer) (McMAHON, 2009).

Num outro blog, o movimento do Evangelho Social organiza a sua defesa:

O nosso movimento não considera a missão da igreja como realização de ações sociais, mas como a busca, em primeiro lugar, do Reino de Deus e da sua justiça. Trata-se da instauração progressiva, ativa e contínua do reino de Deus na terra. Essa ação inclui a luta contra a discriminação racial e a violência que atinge as mulheres, a promoção da igualdade entre homens e mulheres e na sociedade em geral, a supressão da guerra, da fome e da pobreza. Trata-se de combater pela subversão o "sistema das coisas" (o mundo), que alimenta todas as qualidades contrárias ao reino de Deus. O movimento quer ser uma voz profética e ativa na igreja e na sociedade, denunciando as estruturas injustas e convidando a humanidade 
toda à reconciliação dos seres humanos com Deus e com seus irmãos em humanidade. Um exemplo é a campanha contra as leis anti-LGBTI, em defesa de direitos iguais para todos, independentemente da raça, da cor, do gênero, da religião ou da orientação sexual, pois todos são filhos de Deus, justificados gratuitamente pela Sua graça (blog EVANGELHO SOCIAL, 2017).

\subsubsection{A conferência do Nordeste e o movimento Igreja e Sociedade na} América Latina (ISAL) (Cf. BARRETO, 2008)

A origem remota da conferência é a criação da "União dos Estudantes Cristãos do Brasil” (UCEB), resultado da iniciativa de pastores, estudantes, seminaristas e universitários cansados pela falta de participação das igrejas nas lutas sociais. Na ocasião da primeira conferência latino-americana dos estudantes cristãos em 1952, a associação convida um missionário americano, expulso da Colômbia, para discutir a vocação cristã: Richard Shaull. Em vista de debater as questões colocadas pelo marxismo à teologia cristã, ele publicara um livrinho intitulado $O$ cristianismo e a revolução social. Sob o impulso de Richard Shaull e Valdo César, nasce o "Setor de responsabilidade social da igreja" (SRSI) no seio da "Confederação evangélica do Brasil" (CEB), organismo interdenominacional constituído pelas seis igrejas protestantes principais do país. O SRSI organiza quatro conferências sobre temas atuais da sociedade brasileira entre 1955 e 1962: “A responsabilidade social da igreja (1955)", para estudar os fundamentos bíblicos e teológicos da responsabilidade cristã na esfera sociopolítica; “A igreja e as rápidas transformações sociais no Brasil (1957)”, a fim de compreender melhor os processos sociais no Brasil e no mundo; "A presença da igreja na evolução da nacionalidade (1960)" foi um convite a participar de modo solidário dos diversos campos marcados por profundas transformações no Brasil: sociais, econômicos, políticos e culturais. ${ }^{8}$ Já aparece aqui certa frustração a respeito das teorias "desenvolvimentistas", frente aos processos de urbanização e industrialização.

Enfim, a Conferência do Nordeste se reúne em 1962, com o tema: "Cristo e o processo revolucionário no Brasil". Será, ao mesmo tempo, o ápice e o fim das conferências organizadas pelo SRSI. O otimismo

8 As semelhanças são impressionantes com os temas dos primeiros encontros do movimento do socialismo religioso na Suíça e na Alemanha nos anos vinte. 
a respeito das possibilidades de desenvolvimento econômico e social rápido já fora profundamente abalado. Diversos grupos de "oprimidos" estão se organizando, como as ligas camponesas no Nordeste, no chamado "quadrilátero da fome". Faltava a presença da igreja evangélica. A escolha da cidade de Recife para a realização da conferência é significativa: é o centro da região mais empobrecida do país, onde o escândalo da injustiça social é o mais gritante. Em vista de conhecer melhor a realidade da região, a conferência convidou pesquisadores brasileiros conhecidos, economistas e sociólogos, inclusive fora dos meios evangélicos, como Celso Furtado. Por outro lado, já são muito perceptíveis as pressões do Estado e dos setores mais conservadores da igreja. O SRSI é vigiado pela polícia e pelo exército: o golpe de 1964 já está próximo. Depois do golpe de Estado, diversos participantes foram presos, outros terão que fugir do país.

Richard Shaull já tivera que deixar o seminário presbiteriano de Campinas, onde lecionava, e voltar para os Estados Unidos em 1962, antes mesmo da realização da conferência. Ele tinha contribuído, em diálogo com o SRSI, para a criação de ISAL (Igreja e Sociedade na América Latina), organismo reunindo sociólogos e teólogos de diversas igrejas e visando o diálogo com o pensamento revolucionário. Seu principal órgão era a revista Cristianismo y Sociedad, publicada no Uruguay. ${ }^{9}$ Estabelecido no Brasil entre 1953 e 1962, Richard Shaull trabalhou como animador e mediador do movimento da esquerda evangélica. Dedicarei o próximo item à vida e ao pensamento dele.

\subsubsection{O pensamento de Richard Shaull (1919-2002) e a opção socialista (Cf. HUFF JÚNIOR, 2012, p. 56-76)}

Após um período de estudos de mais de dez anos, primeiro em sociologia, no Elizabethtown College - faculdade ligada à Igreja dos Irmãos, de origem pietista-anabatista - e depois em teologia, no seminário teológico de Princeton, Shaull e sua esposa Mildred se inscrevem ao serviço das missões estrangeiras da igreja presbiteriana, em vista de

\footnotetext{
9 Um dos principais animadores do movimento foi o teólogo metodista uruguaio Júlio de Santa Ana, que foi, bem mais tarde, o meu colega na UMESP durante dez anos. Exilado do seu país, trabalhou muitos anos no Conselho Mundial de Igrejas em Genebra e continua participando, até hoje, de diversos movimentos sociais e políticos.
} 
uma missão na América latina. Shaull já estava convencido de que a fé cristã devia levar inevitavelmente à ação. Passou dez anos na Colômbia, onde conhece a situação social dos pobres e percebe a defasagem contextual entre essa situação e a teologia protestante tradicional. Entre em contato com o marxismo e os movimentos sociais e estudantis de esquerda. Mas trata sobretudo dos conflitos entre católicos e protestantes, sofrendo muito por causa dos ataques dos quais os últimos eram vítimas. Em 1951, participa, no Union Theological Seminary de New York, de um grupo de estudos sobre o "desafio do comunismo", dirigido por professores da instituição: Reinhold Niebuhr, John Bennett e Searle Bates. Ele não ficou satisfeito com as críticas ao totalitarismo comunista e tomou consciência do papel desempenhado pelos Estados Unidos na exploração dos países ditos do Terceiro Mundo.

No mesmo local, Shaull encontra também Paul Lehmann, que tinha estudado com Karl Barth e tinha sido amigo íntimo de Dietrich Bonhoeffer. Por intermédio de Lehmann, Shaull se abre aos movimentos revolucionários e marxistas, mas critica o totalitarismo comunista e a escravidão para com a técnica. Após o fim das atividades do grupo de estudos, ele volta a Princeton para continuar o doutorado sob a direção de Lehmann, cuja teologia contextual marcaria profundamente a produção da Teologia da Revolução ou, melhor, segundo Shaull, da "teologia no contexto da revolução". Já vimos que, no Brasil, ele trabalha com o movimento estudantil. Participa também, em 1956, de uma experiência comunitária no meio dos trabalhadores da indústria em São Paulo, inspirada nos padres operários franceses.

Em $O$ cristianismo e a revolução social, publicado no Brasil em 1953 (SHAULL, 1953), ele desenvolve uma teologia que visa a uma práxis cristã socialmente responsável: os cristãos deveriam, para serem fiéis às suas origens e tradições, se aproximar do proletariado e dos movimentos sindicais. Seu discurso é marcado pela velha ascese calvinista intramundana: "Se Jesus Cristo é Senhor acima de todos os principados e poderes, se Deus age no mundo e na sociedade para realizar a Sua vontade e estabelecer o Seu senhorio, então eu, na minha qualidade de cristão, tenho uma enorme responsabilidade na sociedade, estou chamado a testemunhar, em todos os domínios da vida, a respeito deste senhorio de Jesus" (IBID.). Sua crítica do comunismo russo ressaltava 
a noção calvinista de que, exceto o poder de Deus, tudo é provisório, imperfeito e relativo. Shaull manifestava assim uma orientação claramente escatológica, diferente do secularismo comunista.

No Brasil, ele percebe que a busca pelo sentido da vida encontrava mais facilmente uma resposta através da relação entre a "paixão profética pela justiça" e o marxismo, do que entre essa paixão e o cristianismo presente nas igrejas. Durante esses anos, Shaull incorpora à sua teologia a percepção dos problemas sociais mundiais como questões de ordem estrutural ${ }^{10}$, e a aceitação da ideia de que, se o contexto é revolucionário, a teologia deve produzir sentido para a revolução e a intenção revolucionário dos cristãos.

Depois da sua saída do Brasil, Shaull participa em 1966 da consulta ecumênica preparatória à Conferência Mundial Igreja e Sociedade em Genebra, como um dos principais autores e conferencistas. Sua contribuição se intitula $O$ desafio revolucionário à igreja e à teologia (SHAULL, 1966a e 1966b). ${ }^{11}$ Nesse estudo, Shaull desenvolvia um pensamento social ecumênico, que proclamava a obra redentora de Deus na história, e chamava os cristãos para a ação e a construção do Reino de Deus pela transformação da sociedade, em virtude da perspectiva escatológica de que o senhorio de Cristo rompe a ordem estabelecida injusta e chama para a renovação da história. Daí a necessidade de assumir a responsabilidade da revolução e de examinar qual seria a melhor forma concreta da luta revolucionária. Nesse sentido, era urgente elaborar uma ética teológica a partir da vivência, uma ética contextual de ação. Shaull preconizava o uso de "técnicas de guerrilha", inclusive teológicas, na ação política, a fim de exercer constantes pressões sobre os pontos nevrálgicos do sistema. Essas técnicas serão, de preferência, não violentas, salvo em algumas situações, nas quais a mudança seria impossível sem o uso da violência.

Retomando a tradição calvinista e dialética, segundo a qual, frente ao Deus absolutamente soberano, toda construção humana é subalterna

10 Notemos que, para o protestantismo de missão latino-americano, a transformação social só pode ser uma consequência da transformação prévia dos indivíduos que compõem a sociedade. Uma concepção estrutural da sociedade fazia cruelmente falta.

11 Esse texto me impressionou vivamente quando o li no tempo dos meus estudos de teologia em Louvain, onde me preparava também para uma missão no Brasil. 
e submetido ao julgamento, Shaull considerava que os regimes constitucionais, assim como a revolução, estavam debaixo do julgamento de Deus e deviam ser avaliados nesta perspectiva. Em consequência, não deviam ser mantidos a todo custo: "Todas as ordens sociais estão perdendo seu caráter sagrado e se abrem ao futuro, o qual deverá ser configurado pela vontade humana (SHAULL, 1966 a , p. 82)". Ou ainda: "A natureza e a sociedade são realidades temporais que existem para servir os projetos de Deus em relação com os seres humanos. Em consequência, elas podem ser usadas e modificadas para se colocar à altura desses projetos (IBID.)".

$\mathrm{Na}$ Bíblia toda, há um acento escatológico muito forte, que ressalta a natureza dinâmica de Deus e o fato de que sua ação visa um objetivo na história. Nesse sentido, Shaull afirmava o caráter revolucionário do messianismo bíblico e o potencial revolucionário intrínseco da escatologia cristã. Embora a inspiração de Shaull fosse mais barthiana, ele usava um método teológico de mediação próximo do método tillichiano da correlação, com a dialética da situação e da mensagem (Cf. ABREU, 2010, p. 151-177). ${ }^{12}$ No caso dele, trata-se de um encontro dialógico e criativo entre a fé cristã e o espírito revolucionário presente no contexto latino-americano. Esse método leva à ressignificação de aspectos específicos da tradição teológica. Shaull compreende, de fato, a teologia como hermenêutica simbólica, consequência do caráter simbólico das narrativas bíblicas. Será preciso, então, interpretar dialeticamente os símbolos cristãos, assim como as narrativas e linguagens parabólicas oriundas dos textos bíblicos, à luz da experiência existencial contemporânea.

\section{Conclusão}

Neste texto, a questão era de saber se a descrição por Tillich das principais tendências do protestantismo alemão e norte-americano, na perspectiva do compromisso social e político dos cristãos, podia ajudar

12 Vejamos, por exemplo, na Introdução à Era Protestante: "A tarefa da teologia é mediação, mediação entre o critério eterno da verdade, como é manifesto na figura de Jesus enquanto Cristo, e as experiências mutáveis dos indivíduos e dos grupos, suas diversas questões e suas categorias de percepção da realidade. Quando a tarefa mediadora da teologia é rejeitada, é a própria teologia que é rejeitada, pois o termo "teo-logia" implica, em si mesmo, uma mediação entre o mistério que é Theos e a compreensão que é Logos (TILLICH, 1957, p. xiii)." 
na nossa compreensão do protestantismo brasileiro. A resposta é globalmente positiva, sabendo que, como Tillich, trabalhamos com "tipos ideais", que permitem detectar elementos estruturais comuns, sem que se possa falar em perfeita identidade.

Como vimos, o protestantismo brasileiro provém, antes de tudo, das missões organizadas pelo radicalismo evangélico norte-americano, as quais trouxeram ao Brasil a ideia calvinista de dessacralização dos poderes e da construção humana do reino de Deus, pelo estabelecimento do senhorio de Deus sobre os indivíduos e a sociedade, de um lado, e o individualismo religioso radical oriundo dos movimentos sectários, do outro lado. Essa situação pode ter levado as comunidades que constituem o "protestantismo de missão" a uma mistura explosiva de atitudes sociopolíticas contraditórias. Sobretudo, depois que essa forma de protestantismo foi levada a identificar o reino de Deus com a humanidade burguesa, caracterizada pelo individualismo exacerbado e a adesão ao sistema capitalista. As diferenças se devem à mudança, no tempo e no espaço, das condições sociais, culturais, econômicas e políticas. Pode ter resultado tanto um abstencionismo político quanto uma participação em vista de conquistar um espaço social e econômico para as comunidades evangélicas, ou ainda uma crítica radical do sistema econômico e social e um engajamento em vista de uma transformação profunda e até revolucionária. ${ }^{13}$

É que encontramos no protestantismo brasileiro os mesmos contrastes que no calvinismo em geral e anglo-saxão em particular. Em primeiro lugar, encontramos em toda parte uma orientação objetiva e racional e a fé na capacidade do ser humano de se deixar guiar pela razão, do mesmo modo que a valorização da técnica moderna, especialmente em termos de comunicação social (canais de rádio e televisão, sites e blogs na internet). Trata-se sobretudo de mudar a sociedade pela transformação dos indivíduos. Para isso, o acento é colocado na formação da personalidade individual. A conversão individual a um novo modo de existência exige, muitas vezes, a ruptura com o meio cultural e religioso de origem. A espiritualização da existência pode levar ao isolamento ou ao abstencionismo em relação com as questões sociais

13 Nesse sentido, a figura de Richard Shaull é exemplar. 
e políticas. Ao contrário, a visão maniqueísta da separação da igreja e do mundo leva à guerra espiritual, luta implacável contra os demônios ou poderes do mal e intolerância radical frente a todas as diferenças.

Encontra-se, em particular, uma ética crítica e profética frente a uma ética de prescrições morais, no que diz respeito à recusa do jogo, do fumo, do álcool, da droga e da prostituição. O mais importante é a regulação da vida familial e sexual: defesa da família tradicional e da moral cristã e restrição dos direitos da mulher e das "minorias sexuais", luta contra a legalização do aborto, a descriminalização das drogas e a discussão das questões de gênero nas escolas públicas. Do lado oposto, diversos grupos defendem a liberdade individual na escolha de formas de união ou de orientação sexual e apoiam os movimentos feministas e LGBTIQ+. A questão-chave do confronto entre evangélicos conservadores e progressistas é a necessidade - ou não - da intervenção do Estado para exercer uma regulação sobre o corpo, em particular a sexualidade: aborto, homossexualidade e manipulação genética.

Do ponto de vista da ação social, uma corrente fundamentalista rejeita em bloco toda ação social e política. Uma outra corrente insiste na responsabilidade social dos indivíduos e das comunidades. Nota-se a participação de evangélicos em muitos programas e organizações sociais de alívio da pobreza, assistência à saúde, à habitação popular, alfabetização e educação popular, ajuda aos migrantes, luta contra as desigualdades regionais, luta contra o racismo e o machismo e todas as formas de intolerância, sobretudo religiosa, promoção da ética na política, da justiça econômica e de gênero, formação ecumênica de mulheres e jovens. O compromisso, que pode ter sido revolucionário no passado, graças a uma conjuntura mais favorável, oscila hoje entre a crítica estrutural e as obras de caridade.

Como na sociedade em geral, a crítica socialista resiste dificilmente ao movimento global de adesão ao capitalismo e à sociedade de consumo. O espírito burguês foi adotado tanto pelos indivíduos quanto pelas comunidades. Essas dependem sempre mais das grandes forças econômicas e as próprias igrejas tornam-se potências financeiras e midiáticas. Suas construções são caras e ostentatórias. Os evangélicos se identificam como um setor do mercado, especialmente pela produção musical e seus derivados. Isso corresponde, nos indivíduos, à adoção 
da teologia da prosperidade. É que o sucesso social e profissional e a riqueza são entendidos como sinais de eleição religiosa.

A Bíblia, princípio diretor da vida social e política, é, o mais das vezes, interpretada de modo literalista, fundamentalista e autoritário, com a recusa da hermenêutica histórica, exegética e filosófica. Alguns grupos fazem uma leitura política libertadora, como o CEDI. A pertença ao tipo religioso teocrático inclui a preferência pelo Antigo Testamento. A teocracia pode ser conservadora ou progressista, reformista, reacionária ou revolucionária. Por um lado, pudemos assistir à luta pela transformação social estrutural, inclusive socialista e revolucionária, mas, por outro lado, a obsessão pelo perigo comunista totalitário está constantemente presente e reanimada. Encontramos assim duas formas opostas de messianismo político.

A vontade de cristianizar a sociedade pelas obras humanas se apoia na ideia associativa e federativa, como pudemos verificar pela existência de numerosas associações interdenominacionais, de esquerda ou de direita, liberais ou fundamentalistas. Isso corresponde a um uso ambíguo e às vezes maquiavélico dos meios econômicos e midiáticos e da política (cooptação de partidos, blocos parlamentares), em vista de colocar as instituições e os indivíduos em acordo com os mandamentos divinos. Mas esses são também objetos de interpretações contraditórias: a vontade divina pode ser confundida com o crescimento numérico da comunidade ou com a conquista de espaços políticos, econômicos ou midiáticos, favorecendo a influência e a visibilidade das denominações. Assim, muitas vezes, o culto, especialmente a pregação, se confunde com a política denominacional.

Em resumo, entre o protestantismo de raiz calvinista descrito por Tillich e o protestantismo brasileiro, as afinidades e as analogias são numerosas, no melhor e no pior sentido. Os protestantes brasileiros não estão sempre conscientes das influências históricas que eles continuam sofrendo. Um olhar retrospectivo, nem que seja em pensamento, pode ser salutar para evitar doravante os erros do passado e do presente e reassumir iniciativas um tanto quanto esquecidas, em sintonia com a mais autêntica tradição, que poderiam reanimar a esperança nesses tempos sombrios que estamos vivendo. 


\section{Referências bibliográficas}

ABREU, F.-H de. Teologia como Hermenêutica Simbólica: breves considerações sobre o Método Teológico de Richard Shaull. Numen: revista de estudos e pesquisa da religião. Vol. 13, n ${ }^{\circ} 1$ e 2, 2010, p. 151-177.

BARRETO, R. C. JR. A conferência do Nordeste e o movimento Igreja e Sociedade. Revista Ultimato online, $\mathrm{n}^{\circ} 310,2008$. Disponível em http://www. ultimato.com.br/revista/artigos/310/a-conferencia-do-nordeste-e-o-movimento-igreja-e-sociedade. Acesso em 20/08/2017.

CUNHA, M. N. Do púlpito às mídias sociais. Evangélicos na política e no ativismo digital. Curitiba-PR: Prismas, 2017.

EVANGELHO SOCIAL. Disponível em https://oevangelhosocial.wordpress. com. Acesso em 20/08/2017.

FRESTON, P. Evangélicos na política brasileira: história ambígua e desafios éticos. Curitiba-PR: Encontrarão, 1994.

HEAL, B.; KREMER, A. (Eds.) Radicalism and Dissent in the World of Protestant Reform. Göttingen: Vandenhoeck\&Ruprecht, 2017.

HIGUET, E. Le protestantisme au Brésil entre le conservatisme et la transformation sociale. En dialogue avec les réflexions de Paul Tillich sur le protestantisme allemand et nord-américain. In: Asmar, R.; Danz, C.; Leiner, M.; and Lon, M. (eds). Reformation und Revolution in der Wahrnehmung Paul Tillichs - Réformation et révolution dans la perception de Paul Tillich Paul Tillich's Perceptions into Reformation and Revolution. Berlin: De Gruyter, 2019, Tillich Research, 18, p. 369-395.

HUFF Jr. A. E. Teologia e revolução: a radicalização teológico-política de Richard Shaull. Estudos de religião, vol, 26, n 43, 2012, p. 56-76.

McMAHON, T. A. o vergonhoso Evangelho Social. Chamada da Meia-Noite, janeiro de 2009. Disponível em: http://www.chamada.com.br/mensagens/evangelho_social.html. Acesso 27/12/2017.

MENDONÇA, A. G. Um panorama do protestantismo brasileiro atual. In: LANDIM, L. (org.). Sinais dos Tempos. Tradições religiosas no Brasil. Rio de Janeiro: ISER, 1989, p. 37-86.

OSHATZ, M. Social Gospel. In: KUTLER, S.-L. Dictionary of American History. New York: Charles Scribner'Sons, 3ª. Ed., 2003.

RICHARD, J. Introduction. In: TILLICH, P. La dimension religieuse de la culture. Paris/Genève/Québec: Cerf/Labor et Fides/Laval, 1990, p. 13-27.

RICHET, L. De l'utopie socialiste au réalisme chrétien - Reinhold Niebuhr et le New Deal. Transatlantica 1, 2006. 
SHAULL, R. O cristianismo e a revolução social. São Paulo: União cristã de estudantes do Brasil, 1953.

SHAULL, R. Point de vue théologique sur la révolution. In: EGLISE ET SOCIÉTÉ. Éthique sociale chrétienne dans un monde en transformation. Une enquête oecuménique. Genève: Labor et Fides, 1966a. Vol. 1, p. 13-28.

SHAULL, R. The revolutionary Challenge to Church and Theology. The Princeton Seminary Bulletin, vol. 60, no 1, 1966b, p. 25-32. Disponível em http:// sede.library.ptsem.edu/mets_aspx?src=PSB19666010\&div=7.

TILLICH, P. Author's Introduction. In: The Protestant Era. Chicago: The University of Chicago Press, 1957, p. v-xxvi.

TILLICH, P. The Protestant Era. Chicago: The University of Chicago Press, 1957.

TILLICH, P. Histoire de la pensée chrétienne. Paris: Payot, 1970.

TILLICH, P. La situation religieuse du temps présent. In: La dimension religieuse de la culture. Paris/Genève/Québec: Cerf/Labor et Fides/Laval, 1990, p. 179-247.

TILLICH, P. Protestantisme et romantisme politique. In: Écrits contre les nazis (1932-1935). Paris/Genève/Québec: Cerf/Labor et Fides/Laval, 1994a, p. 5-16.

TILLICH, P. L’État total et la prétention des églises. In: Écrits contre les nazis (1932-1935). Paris/Genève/Québec: Cerf/Labor et Fides/Laval, 1994b, p. $185-214$.

TILLICH, P. La situation religieuse actuelle en Allemagne. In: Écrits contre les nazis (1932-1935). Paris/Genève/Québec: Cerf/Labor et Fides/Laval, 1994c, p. 171-184.

TILLICH, P. The social functions of the Churches in Europe and America. Social Research, vol. 3, nº 1, 1936, p. 90-104. Trad. Alemã: Die Bedeutung der Kirche für die Gesellschaftsordnung in Europa und Amerika. In: Das religiöse Fundament des moralischen Handelns. Schriften zur Ethik und zum Menschenbild. Gesammelte Werke, Band III. Stuttgart: Evangelisches Verlagswerk, 1965, p. 107-119.

TILLICH, P. La naissance de l'esprit moderne et la théologie protestante. Paris: Cerf, 1972. 